\title{
頸部主幹動脈の動脈硬化性病変に対する PTA 治療の経験
}

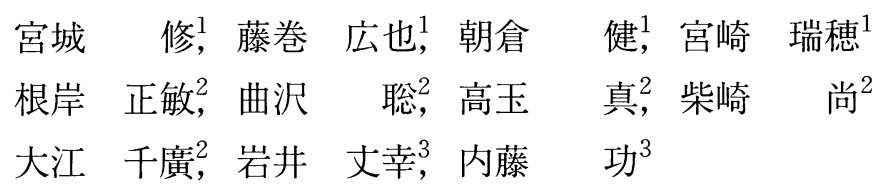

\section{Percutaneous Transluminal Angioplasty for Arteriosclerotic Stenosis of Cervical Supra-aortic Arteries}

Osamu Miyagi, M.D., ${ }^{1}$ Hiroya Fujimaki, M.D., ${ }^{1}$ Ken Asakura, M.D., ${ }^{1}$

Mizuho Miyazaki, M.D., ${ }^{1}$ Masatosi Negishi, M.D., ${ }^{2}$ Satoru Magarisawa, M.D., ${ }^{2}$

Shin Takadama, M.D., ${ }^{1}$ Takashi Shibazaki, M.D., ${ }^{1}$ Chihiro OHye, M.D., ${ }^{2}$

Tomoyuki IwAI, M.D., ${ }^{3}$ and Isao NAITo, M.D. ${ }^{3}$

${ }^{1}$ Department of Neurosurgery, Maebashi Red Cross Hospital,

${ }^{2}$ Department of Neurosurgery, Gunma University School of Medicine, and

${ }^{3}$ Department of Neurosurgery, Geriatric Research Institute and Hospital,

Maebashi, Japan

Summary : Eleven patients with supra-aortic artery stenoses were treated with percutaneous transluminal angioplasty (PTA). These cases included 8 vertebral arteries, 3 internal carotid arteries, and 2 subclavian arteries. Minor complications occurred in 3 cases. One internal carotid artery and 1 femoral artery suffered from intimal dissection; bradycardia and mild hypotention due to carotid sinus reflex occurred in another case. No permanent complications were experienced. Except for one stenosis at the origin of vertebral artery and one case of subclavian artery, stenoses were dilated with good results. During the follow-up of 3 to 12 months (mean: 9 months) in 10 patients, 3 stenoses at the origin of vertebral aretry were involved with restenosis. All the patients with stenoses of internal carotid arteries and trunk of vertebral arteries have been treated with satisfactory dilatations. In only 1 stenosis at the origin of vertebral artery, recurrent cerebellar infarction appeared 6 months after PTA.

According to pathological and hemodynamic studies, the stenoses of vertebral and subclavian arteries can be treated by PTA safely. However, for fear of embolism, the application of PTA in the stenoses of internal carotid arteries is still controversial. To prevent embolism, balloon-mounted guiding catheters were used in our internal carotid lesions. On the basis of our own results, PTA is a useful method for supra-aortic artery stenoses.
Key words :

- percutaneous transluminal angioplasty

- arteriosclerotic stenosis

- supra-aortic arteries

\footnotetext{
1前橋赤十字病院 脳神経外科, ${ }^{2}$ 群馬大学 脳神経外科, ${ }^{3}$ 老年病研究所付属病院 脳神経外科(受稿日 1992.5.6)
} 
はじめに

1964 年, Dotter \& Judkins ${ }^{6)}$ が percutaneous transluminal angioplasty（PTA）による治療を考案した。その 後, balloon catheter の改良に伴い, 冠動脈に限らず腎動 脈や四肢血管の狭窄病変にも応用され, 良好な結果を得て きた.しかし, 脳へ血液を供給する頸部主幹動脈の狭窄病 変では, 末梢への塞栓が危惧され, 適用されることがなか った. 1980 年に Kerber ${ }^{11)}$ が総頸動脈の狭窄病変を balloon catheter を用いて拡張し，1981 年に椎骨動脈の PTA 症例を Motarjeme ${ }^{13)}$ が報告した. その後, 頸部主幹動脈 の動脈硬化性狭窄病変に対するPTA が数多く試みられて いる. 我々は 11 例の頸部主幹動脈の狭窄病変に対し, 再 発予防の目的で PTA 治療を試みた. 手技や適応について 述べるとともに, その後の follow-up study から若干の知 見を得たので報告する。

\section{対象および方法}

11 症例の内訳は 8 椎骨動脈, 3 内頸動脈, 2 鎖骨下動脈 の合計 13 血管で，男性 9 .人，女性 2 人，年齢は 55 歳から 67 歳である. 椎骨動脈症例中 5 血管は起始部, 2 血管は first portion $\left(\mathrm{V}_{1}\right), 1$ 血管は second portion $\left(\mathrm{V}_{2}\right)$ の狭窄病 変であった． 2 例の鎖骨下動脈病変では血管撮影で subclavian steal phenomenon が確認された. 内頸動脈 3 例の 狭窄部は総頸動脈分岐部より末梢に存在した. 11 例中 1 例 (Case 7) は同側の内頸動脈と椎骨動脈に狭窄を認め, 1 例 (Case 1) は両側の椎骨動脈に狭窄が存在した. 方法は大 腿動脈経由で，椎骨動脈症例に対しては拡張時外径 1.5 $4.0 \mathrm{~mm}$ の PTCA 用 balloon catheter を使用した. 内頸動
脈病変に対しては 5〜6 mm, 鎖骨下動脈病変では $6 \sim 8$ $\mathrm{mm} の$ balloon catheter を使用した. PTA balloonの拡張 は 6〜8 気圧-90 秒-3 回を基準にして行った. 術中の血栓 形成を予防するためにへパリン 3,000 単位を静脈内投与し 終了後は同血管内にウロキナーゼ 12 万単位を注入した. さらに翌日までへパリン 5,000 単位 $/ 1,000 \mathrm{~m} l$ の持続点滴 を行った. 以下に代表例を提示する.

\section{$<$ Case 4> 66 歳, 男性.}

1991 年 8 月 12 日, 右上下肢のしびれが出現し, 翌日に は失調性歩行, 複視がみられたため来院した. 血管撮影に て右椎骨動脈閉塞と左椎骨動脈起始部の $90 \%$ 以上の狭窄 が確認され，薬物療法を試みたが，失調性歩行と複視を反 復したため, 11 月 15 日，PTAを行った。最初に外径 2 $\mathrm{mm}$ の balloon で 8 気圧 -90 秒-3 回, 次に $4 \mathrm{~mm} の$ balloon で同様にPTA を行い, 十分な拡張が得られた。術中 に虚血症状は認められず, 術後 1 週目頃から症状は消失し た. 手技中に introducing sheath による大腿動脈の内膜剥 離を生じたが，特に問題は見られなかった. 6 力月後の血 管写で $50 \%$ の再狭窄を認めたが, 症状の再発は認めてな い(Fig. 1).

\section{$<$ Case 8> 65 歳, 男性.}

1991 年 6 月 13 日, 左半身麻痺と知覚障害で発症し, 痤 攣重積状態に陥ったため, 翌日, 当科に紹介された。 CT. scan にて右大脳半球と基底核に梗塞巣が認められ, 脳血 管撮影で右内頸動脈に $80 \%$ の狭窄部が確認された。 入院 後, 左半身麻瘏の改善傾向を認めたこと, 2 回の狭心症発 作を生じたことから，再発を予防する目的で，7月 5 日，

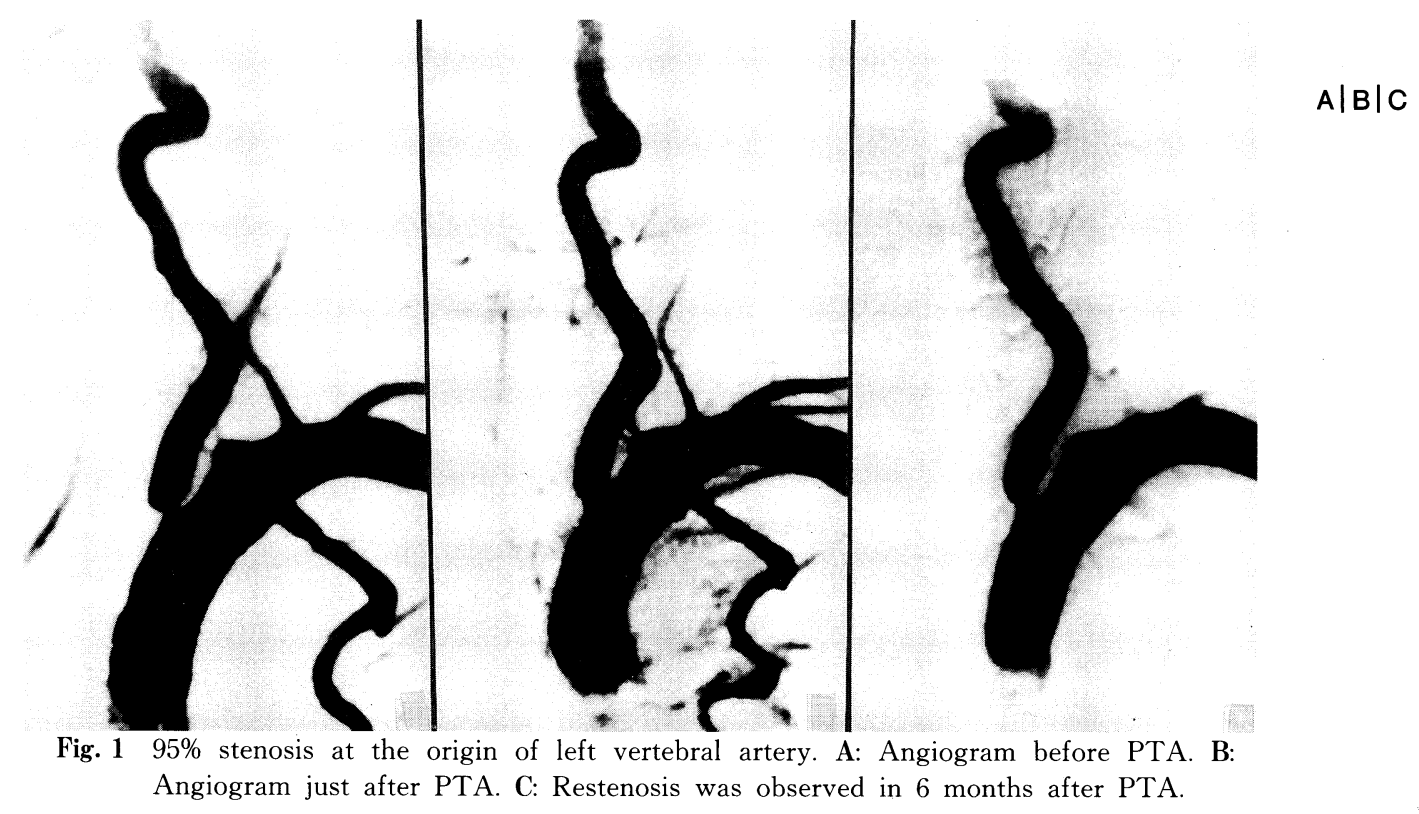

142 脳卒中の外科 $21: 1993$ 


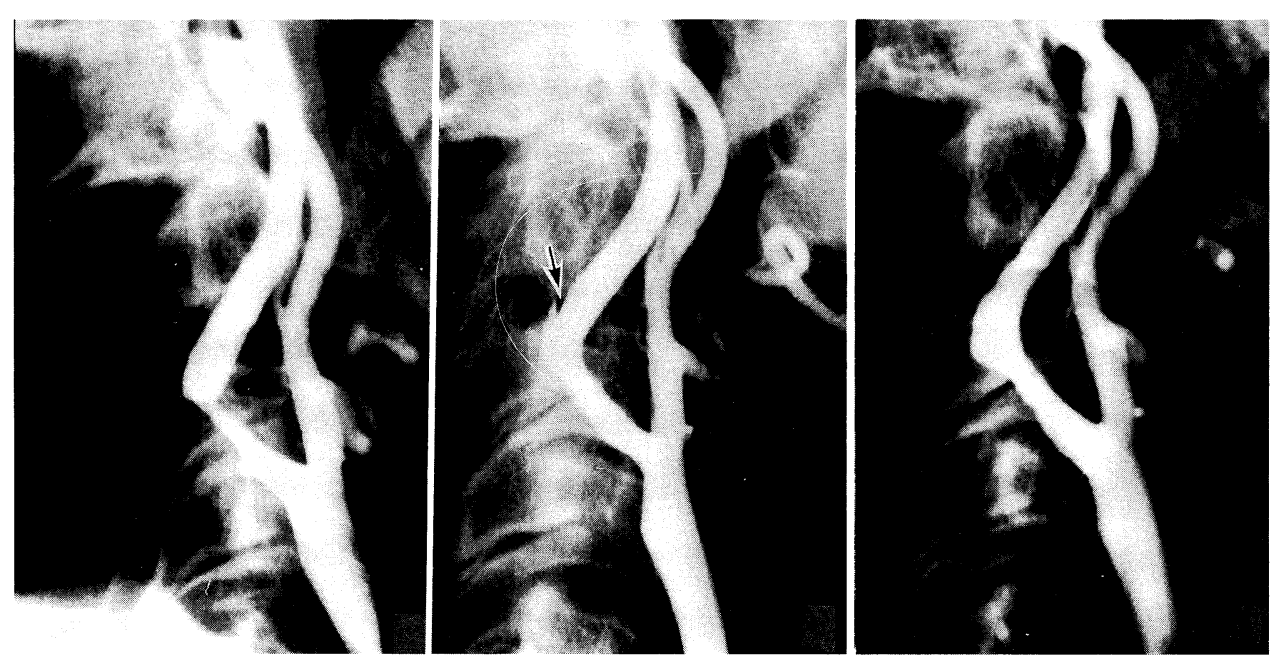

$A|B| C$

Fig. 2 80\% stenosis of right internal carotid artery. A: Angiogram before PTA. B: Angiogram just after PTA. Intimal dissection caused with tip of balloon catheter (arrow). C: Mild restenosis was observed in 12 months after PTA.

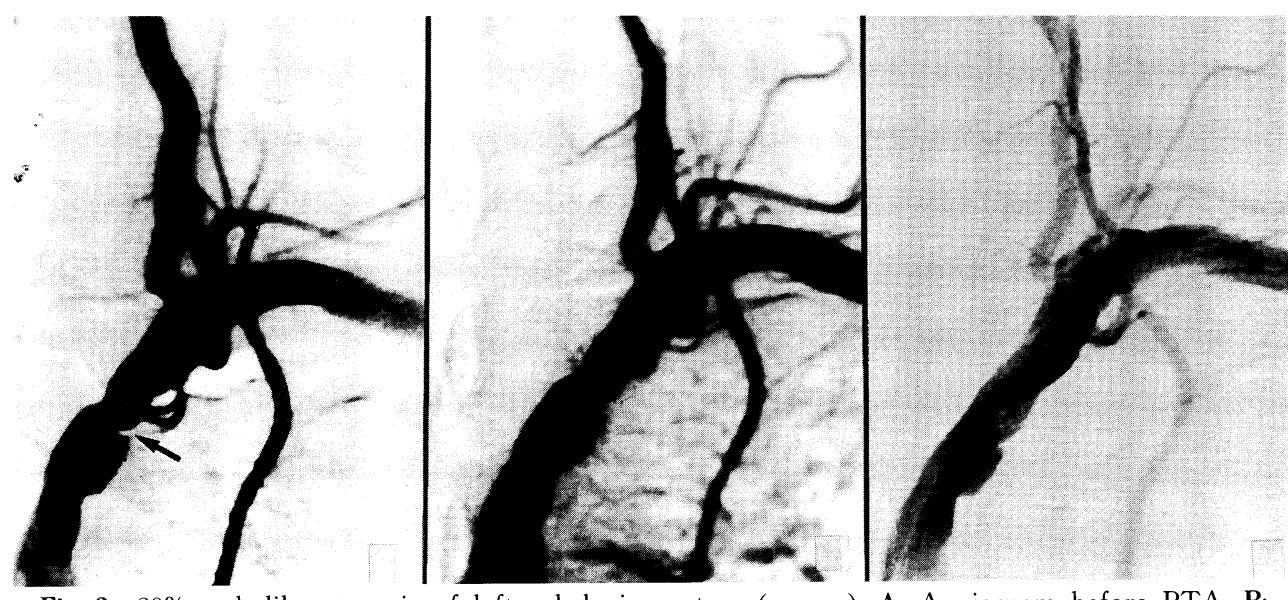

$A|B| C$

Fig. 3 80\% web like stenosis of left subclavian artery (arrow). A: Angiogram before PTA. B

Angiogram just after PTA. C: No restenosis was observed in 10 months after PTA.

侵襲の少ないPTA を試みた，外径 $5 \mathrm{~mm}$ と $6 \mathrm{~mm}$ の balloon を用いて, 各々 8 気圧 -90 秒 -4 回の PTA を行い, 十 分な血管拡張を得た。狭窄部の末梢に catheter の先端に よる内膜剝離を生じたが，臨床的に問題はなかった（Fig 2). 退院時には左半身麻痺は改善し，12 力月後の血管写 で軽度の再狭窄を認めたが, 脳梗塞の再発はなかった.

\section{$\langle$ Case 10>64 歳, 男性.}

1991 年 7 月 15 日，左上肢の脱力感と構音障害があり近 医を受診した。 7 月 23 日，当科受診時には構音障害は改 善していたが, 左上肢の重い感じがあった。 セルジンガー 法による左椎骨動脈撮影の際に椎骨動脈に流れた造影剂が 鎖骨下動脈に逆流する所見がみられた。これは左鎖骨下動 脈近位部に $80 \%$ の web like stenosis (水かき様狭窄)があ り，5Fr. の血管撮影用カテーテルが狭窄部を閉塞し, sub- clavian steal の状態を生じたものと考えられた. 9 月 2 日， 狭窄部の完全閉塞の予防を目的にPTA を行った。術中に balloon catheter を利用して狭窄部周辺の動脈圧を測定し たところ狭窄部の近位部で $170 \mathrm{mmHg}$, catheter が狭窄部 を閉塞した状態の末梢部圧は $80 \mathrm{mmHg}$ であった. 外径 8 $\mathrm{mm}$ の balloon catheter を用いて 6 気圧-90 秒-3 回の PTA を行い，満足すべき拡張が得られた (Fig. 3). PTA 後の 狭窄部末梢の動脈圧は $120 \mathrm{mmHg}$ であった。9月 3 日, 退院し， 2 週間後には左上肢の重い感じも消失した. 10 力 月後の血管写で良好な拡張が確認され, 症状の再発はみら れていない.

\section{結 果}

PTA の結果を評価するために，血管写上の PTA 後の 残存狭窄度が 10\%以下を excellent，10～50\%を good, 
Table 1 Clinical presentation and results of PTA

\begin{tabular}{|c|c|c|c|c|c|c|}
\hline \multirow[b]{2}{*}{ Symptoms } & \multirow{2}{*}{$\begin{array}{l}\text { Lesion } \\
\text { Location }\end{array}$} & \multirow{2}{*}{$\frac{\text { Preangioplasty }}{\text { Stenosis(\%) }}$} & \multicolumn{2}{|c|}{ Postangioplasty } & \multirow[b]{2}{*}{ Complication } & \multirow{2}{*}{$\begin{array}{l}\text { Clinical results } \\
\text { (Recurrence and } \\
\text { new symptoms) }\end{array}$} \\
\hline & & & $\begin{array}{l}\text { Stenosis(\%) (An } \\
\text { just after PTA }\end{array}$ & $\begin{array}{l}\text { ingiographic results) 〈Months〉 } \\
\text { follow up results }\end{array}$ & & \\
\hline 1. diplopia, ataxia & $I-V \cdot A^{*}$ & $90 \%$ & $25 \%$ (good) & $30 \%$ (good) 〈6Mo. $\rangle$ & nothing & r-cerebellar infarc- \\
\hline$r$-hemiparesis & $r-V \cdot A$ & $90 \%$ & $75 \%$ (poor) & $70 \%$ (poor) 〈6Mo. $\rangle$ & " & tion, 6Mo. after PTA \\
\hline \multirow[t]{2}{*}{ 2. drop attack } & $\mathrm{I} \cdot \mathrm{V} \cdot \mathrm{A}$ & $95 \%$ & $40 \%$ (good) & $40 \%$ (good) 〈12Mo. $\rangle$ & $" \prime$ & improved, $\mathrm{R}(-), \mathrm{N}(-)$ \\
\hline & $r-V \cdot A$ & hypoplasty & & & & \\
\hline \multirow[t]{2}{*}{ 3. $r$-hemiparesthesia } & $r-V \cdot A$ & $90 \%$ & $20 \%$ (good) & $60 \%$ (poor) $\langle 10 \mathrm{Mo}\rangle$. & $" 1$ & improved, $\mathrm{R}(-), \mathrm{N}(-)$ \\
\hline & $I-V \cdot A$ & occlusion & & & & \\
\hline \multirow{2}{*}{$\begin{array}{l}\text { 4. diplopia, r-hemi- } \\
\text { paresthesia }\end{array}$} & $I-V \cdot A$ & $95 \%$ & $5 \%$ (excellent) & $50 \%$ (poor) 〈6Mo. $\rangle$ & femoral art. & improved, $\mathrm{R}(-), \mathrm{N}(-)$ \\
\hline & $I-V \cdot A$ & occlusion & & & dissection & \\
\hline \multirow[t]{2}{*}{ 5. truncal ataxia } & $I-V \cdot A^{*}$ & $90 \%$ & $40 \%$ (good) & $10 \%$ (exellent) $\langle 6 \mathrm{Mo}\rangle$. & nothing & improved, $\mathrm{R}(-), \mathrm{N}(-)$ \\
\hline & $r-V-A$ & occlusion & & & & \\
\hline \multirow[t]{2}{*}{ 6. r-leg weakness } & $r-V \cdot A$ & $80 \%$ & $30 \%$ (good) & $80 \%$ (poor) 〈4Mo. $\rangle$ & $\prime \prime$ & improved, $\mathrm{R}(-), \mathrm{N}(-)$ \\
\hline & $I-V \cdot A$ & hypoplasty & & & & \\
\hline \multirow[t]{3}{*}{ 7. $r-1 / 4$ hemianopsia } & $r-V \cdot A^{* *}$ & $75 \%$ & $5 \%$ (excellent) & $0 \%$ (excellent) $\langle 7 \mathrm{Mo}\rangle$. & $\prime \prime$ & \multirow{3}{*}{ no change, $R(-), N(-)$} \\
\hline & $I-V \cdot A$ & hypoplasty & & & & \\
\hline & $r-1 \cdot C$ & $90 \%$ & $0 \%$ (excellent) & $0 \%$ (excellent) $\langle 6 \mathrm{Mo}\rangle$. & $\prime \prime$ & \\
\hline 8. I-hemiparesis & $r-1 \cdot C$ & $80 \%$ & $20 \%$ (good) & $30 \%$ (good) 〈12Mo. $\rangle$ & $\begin{array}{l}\text { intimal } \\
\text { dissection }\end{array}$ & improved, $\mathrm{R}(-), \mathrm{N}(-)$ \\
\hline 9. TIA(I-arm weakness) & $r-1 \cdot C$ & $80 \%$ & $30 \%$ (good) & $20 \%$ (good) 〈4Mo. $\rangle$ & bradycardia & $R(-), N(-)$ \\
\hline $\begin{array}{l}\text { 10. dysarthria, dull- } \\
\text { ness of left arm }\end{array}$ & I-S•A & $80 \%$ & $10 \%$ (excellent) & $10 \%$ (excellent) 〈10Mo. $\rangle$ & nothing & improved, $\mathrm{R}(-), \mathrm{N}(-)$ \\
\hline 11. gait disturbance & $\mathrm{I}-\mathrm{S} \cdot \mathrm{A}$ & $80 \%$ & $60 \%$ (poor) & not examine & $\prime$ & no change, $N(-)$ \\
\hline
\end{tabular}

$\mathrm{V} \cdot \mathrm{A}$ : vertebral artery, $\mathrm{I} \cdot \mathrm{C}:$ internal carotid artery, $\mathrm{S} \cdot \mathrm{A}:$ subclavian artery, $\mathrm{R}:$ recurrence, $\mathrm{N}:$ new symptoms, excellent : residual stenosis $\leqq 10 \%$, good : $10 \%<$ residual stenosis $\leqq 50 \%$, poor : residual stenosis $>50 \%$,

$*$ first portion of vrtebral artery, ** second portion of vertebral artery.

$50 \%$ 以上を poor とした. PTA 直後の評価では，椎骨動脈 では起始部狭窄の 5 血管は, excellent : $1, \operatorname{good}: 3$, poor : 1 で， $\mathrm{V}_{1}$ および $\mathrm{V}_{2}$ 狭窄の 3 血管は, excellent : 1, good : 2 であった. 内頸動脈狭窄の 3 血管では excellent : 1 , good : 2 , 鎖骨下動脈狭窄例は excellent: 1, poor: 1, という結 果が得られた (Table 1). PTA 中およびPTA 後に虚血症 状を呈した症例はなかったが，内頸動脈病変で，1例に狭 窄部の末梢に無症候性の内膜剝離を，他の 1 例で PTA 中 に頸動脈洞反射による徐脈と血圧低下 (収縮期血圧 80 $\mathrm{mmHg}$ ) があった．椎骨動脈起始部の症例で poor の 1 例 (Case 1) は狭窄部に石疢化を伴っていると思われ, PTA 後に石灰化の部分が陰影欠損として描出された(Fig. 4). この症例は 6 力月後に右小脳梗塞の再発をみた。拡張が不 十分であった鎖骨下動脈狭窄例 (Case 10) は，血管撮影中 に左上肢の運動負荷を行うと, subclavian steal phe-
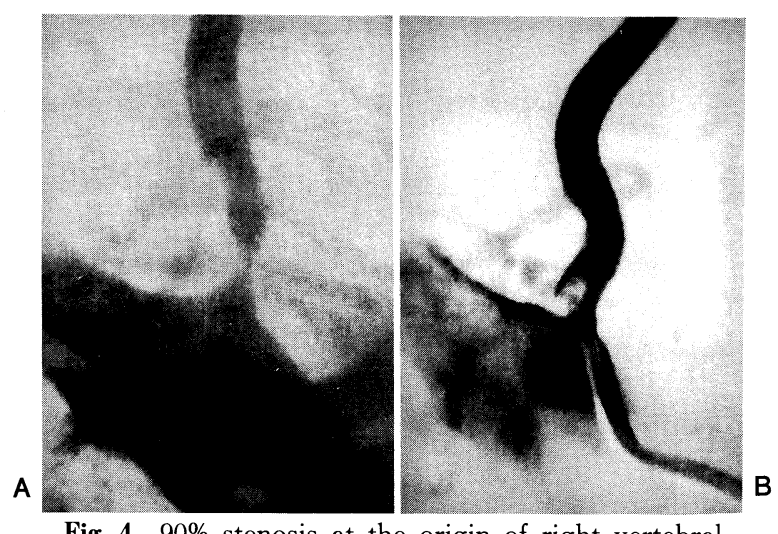

Fig. $490 \%$ stenosis at the origin of right vertebral artery. A: Angiogram before PTA. B: Angiogram just after PTA. Protruding shadow was considered as calcification of stenosis. 

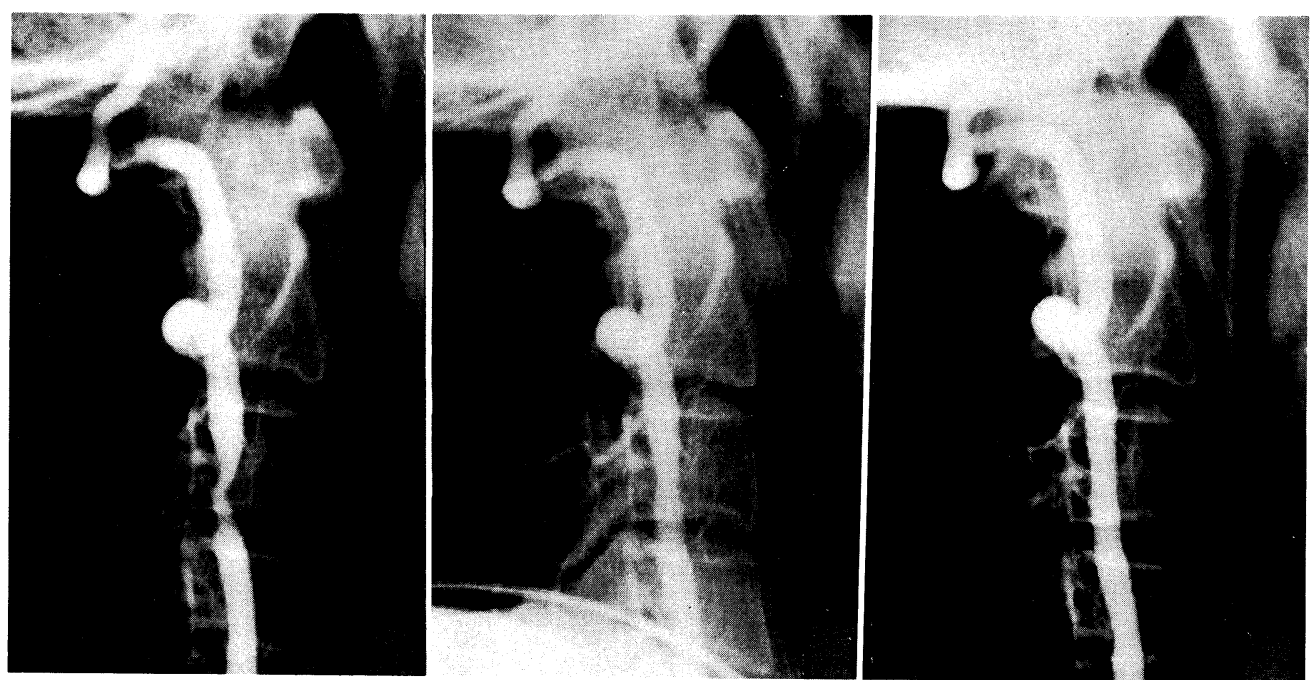

$A|B| C$

Fig. 5 75\% stenosis at the second portion of right vertebral artery. A: Angiogram before PTA. B Angiogram just after PTA. C: Stenosis disappeared completely in 7 months after PTA.

nomenon がみられ，動脈径は $12 \mathrm{~mm}$ と太く，適合する PTA balloon を入手できず，外径 $8 \mathrm{~mm} の$ PTA balloon を用いた．拡張は不十分であったが，術後の血管撮影で subclavian steal phenomenon は改善した.

1 例を除き 4 力月から 12 力月 (平均 9 力月)の follow-up study が行えた. 椎骨動脈起始部狭窄例において, excellent と $\operatorname{good} の 4$ 例中 3 例が再狭窄のため poor と評価さ れたが， $\mathrm{V}_{1}, \mathrm{~V}_{2}$ 狭窄例では，再狭窄はみられず，その後 の血管写で,さらに狭窄部の改善を認めた症例もみられた (Fig. 5). 内頸動脈狭窄例では, 1 例で軽度の再狭窄が見 られたが，他の 2 例では十分な拡張が維持されていた。鎖 骨下動脈狭窄例は 1 例のみ追跡しえたが, 再狭窄はなく, むしろ内壁の平滑化が見られた. 臨床的には, 1 例で再梗 塞を生じた以外に，再発や新たな症状は認めていない。

\section{考察}

\section{1. 椎骨・鎖骨下動脈狭窄病変に対するPTA}

現在までに，椎骨動脈起始部や鎖骨下動脈の狭窄に対す る PTA の有用性について多くの報告があるが314)7)，一 つはこの部位の外科的処置が困難で, 習熟した外科医によ っても morbidity : 10 23\%, mortality : $2 \%$, と合併症が 多いことである5). またPTA が比較的安全に行える要因 として, 椎骨動脈起始部の病変では潰瘍形成が少ないこと 8) , 鎖骨下動脈狭窄例で subclavian steal phenomenon を 呈している逆行性の血流が，PTA 後に順行性に戻るには 20 秒以上を要すること ${ }^{14)}$ などが, PTAに伴う末梢塞栓の 危険性を少なくしているものと考えられている.

現在までに鎖骨下動脈狭窄の PTA 症例は 436 例が報告 され, success rateは $96.1 \%$, permanent damage を生じ
た major complication : $0.2 \%$ ，一過性の minor complication : $4.1 \%$ と外科治療にまさる結果を得ているが, 完全 閉塞例では success rate は 15〜30\% と不満足な結果であ る.また椎骨動脈の PTA 症例は136 例が報告され, success rate : $94.8 \%$, major complication : 0\%, minor complication : $4 \%$ と良好な結果が報告されている ${ }^{10)}$.

我々が経験した椎骨・鎖骨下動脈の PTA 治療例で，鎖 骨下動脈の 1 例を除く 10 血管の follow-up study では, 椎 骨動脈の $\mathrm{V}_{1}$ および $\mathrm{V}_{2}$ 狭窄例は再狭窄が少なく, 数力月 後にさらに拡張を示した症例もみられた。椎骨動脈起始部 狭窄例で, PTA 直後に十分な拡張が得られなかった症例 は，狭窄部の石灰化が予想された。 またPTA 直後は good 以上であった 4 血管中 3 血管で著しい再狭窄をみた. このように椎骨動脈起始部の狭窄病変は PTA 治療に抵抗 する傾向が見られたが, その一因として, 同部は鎖骨下動 脈からの移行部に当り, 鎖骨下動脈の硬化性变化も狭窄病 変になんらかの影響を与えていることが予想され, 病理学 的検討が待たれるところである。 さらに, 補助検査として 血管内超音波内視鏡などによる狭窄部の性状を把握するこ とも重要と思われた. 今後, 再狭窄血管に対して行われる PTA の効果も興味ある問題である.

現在, 我々は, 椎骨動脈狭窄における PTA 治療の対象 を対側血管の閉塞や低形成を伴った狭窄病変，あるいは両 側性の狭窄病変に限り, 一側の椎骨動脈が十分な血流を維 持していると思われる症例は除外しているが, Case 1 の ように一側の狭窄部が十分に拡張されたにもかかわらず， 梗塞の再発を生じた例や, 対側から十分な血流が維持され ている片側性病変で小脳梗塞を生じた例を考慮すると, 一 側性の狭窄例に対しても PTA 治療の適応があると考えて 


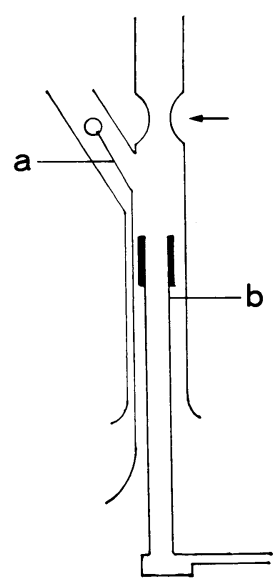

A

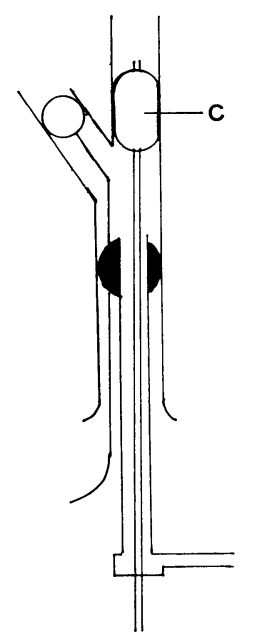

B

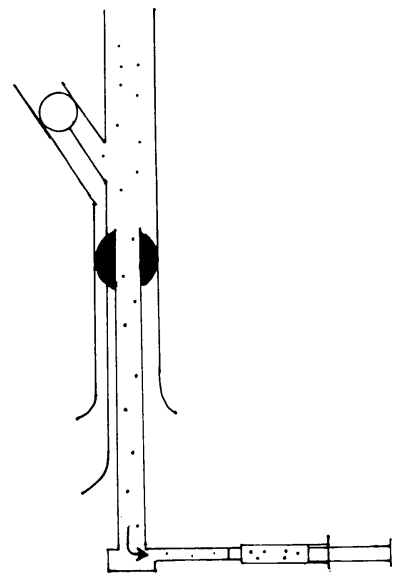

C

Fig. 6 Schemata indicate prevention of embolism with PTA of internal carotid artery. A: Balloon mounted guiding catheter is placed in common carotid artery and occlusive balloon is placed in external carotid artery. Arrow shows stenosis of internal carotid artery. B: Angioplasty is performed. Other balloons are inflated just before finish of angioplasty. C: After deflation and withdrawal of angioplasty balloon, embolic materials are aspirated through the guiding catheter. Occlusive balloon dams up blood flow from external carotid artery to internal carotid artery. $a=$ occlusive balloon catheter, $\mathrm{b}=$ balloon mounted guiding catheter, $\mathrm{c}=$ angioplasty balloon catheter.

いる.

鎖骨下動脈狭窄の 1 例 (Case 11) は無症候性の狭窄病変 と考えられたが，血管撮影中に左上肢の運動負荷により， subclavian steal phenomenon が観察され, 同血管の完全 閉塞に対する治療の困難さを考慮すると，予防的に PTA を行うことも適応の一つと考えられる.

\section{2. 内頸動脈狭窄病変に対するPTA}

内頸動脈の狭窄病変に対する PTAについては，椎骨動 脈と異なりこの部の狭窄病変は潰瘍形成を伴っていること が多く ${ }^{9)}$, PTAによる末梢への塞栓が懸念されるため, 一般的な治療にいたっていない.

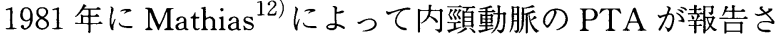
れ，その後，数多くの報告が見られているが2１7）, Kachel $ら^{10)}$ は 35 例の内頸脈狭窄に対してPTA を行い, 恒久的な神経脱落症状の合併はなかったと報告している。 彼らは111-indium platlet scintigraphy を行うことで血栓 の有無を確認し，血栓を有する症例はPTA 治療から除外 している，さらに，Theron ら ${ }^{16)}$ は，末梢塞栓を予防する ために, 狭窄部の末梢を他の balloon で一時的に閉塞し,

遊離した塞栓物質をガイディング・カテーテルから吸引す る方法を考案している，それによって潰瘍形成の疑われる 症例にも PTA が適用できると述べている. 我々はバルー
ン付きのガイディング・カテーテルを用いて狭窄部の近位 部を一時的に閉塞し, 内頸動脈のバック・フローを利用し 血液を吸引除去することで，塞栓が末梢へ遊離するのを予 防している (Fig. 6). また, 末梢塞栓を生じた場合の処置 として，高橋 ${ }^{15)}$ は即座に t-PA を局所注入することで合併 症を回避しており, 補助的な薬剤療法の重要性を述べてい る.

現在までに内頸動脈狭窄に対するPTA の報告は 177 例 あり, success rate : $93.2 \%$, major complication : $1.7 \%$, minor complication : $2.3 \%$, mortality rate : $0 \%$ で，外科 治療における perioperative stroke rate : $5.1 \%$, mortality rate $: 2.3 \%{ }^{1)}$ に劣らない結果を報告している ${ }^{10)}$.

我々が経験した内頸動脈狭窄例は 2 例 (Case 7，9) が冠 動脈バイパス手術を受けており，1例 (Case 8) は入院中に 反復する狭心症発作を認めたため, 侵襲の少ないPTA 治 療を行った．手技中に 1 例で頸動脈洞反射による徐脈と血 圧低下をみたが，アトロピンを用いることで症状は速やか に解消し，新たな合併症もなく翌日退院した. follow-up study では， 1 例に軽度の再狭窄を認めたが，他の 2 例で は十分な拡張が維持されており，その中の 1 例では 4 力月 後の血管写で, PTA 直後に比べてさらに狭窄部の拡張が 確認された。

内頸動脈狭窄病変に対するPTA の適応については，血 
栓を伴う潰瘍形成がなく, 狭窄部に屈曲がないこと, 大動 脈弓近位部や高位の病变で手術が困難な症例や内膜剝離術 後の再狭窄例があげられるが, 我々の症例のように心疾患 を合併し，全身麻酔が負担となる患者に対しても良い適応 と考えられる.

$$
\text { まと め }
$$

椎骨動脈起始部の狭窄例は, PTA 後に高率に再狭窄が みられ，今後，再狭窄に対する PTAの効果を検討する必 要がある. 椎骨動脈幹部や内頸動脈の狭窄病変に対する PTA は, 術後の追跡結果からも良好な結果が得られ, PTAの良い適応と考えられた. さらに長期の追跡結果に よる評価が必要であるが，本治療法は手技が容易で，虚血 時間が短いこと，治療中に患者と意志の疎通が可能なため 不測の事態に即座に対応でき，再治療も可能であるなど多 くの利点を有し，末梢塞栓が確実に予防されるようになれ ば，頸部主幹動脈の狭窄病変において，有力な治療法にな るものと期待できる.

\section{文献}

1) Brott TG, Labutta RJ, Kempczinski RF: Changing pattern in the practice of carotid endarterectomy in a large metropolitan area. JAMA 255: 2609-2612, 1986

2) Brown MM, Butler P, Gibbs J, et al: Feasibility of percutaneous transluminal angioplasty for carotid artery stenosis. J Neurol Neurosurg Psychiatry 53: 238-243, 1990

3) Brückmann $\mathrm{H}$, Ringelstein EB, Buchner $\mathrm{H}$, et al: Percutaneous transluminal angioplasty of the vertebral artery. A therapeutic alternative to operative reconstruction of proximal vertebral artery stenoses. J Neurol 233: 336-339, 1986

4) Courtheoux P, Tournade A, Theron J: Transcutaneous angioplasty of vertebral artery atheromatous ostial stricture. Neuroradiology 27: 259-264, 1985
5) De Ros Reyes RA, Ausman JI, Disz FG: The surgical management of vertebro-basilar insufficiency. Acta Neurochir (Wien) 68: 203-216, 1983

6) Dotter CT, Judkins MP: Transluminal treatment of arteriosclerotic obstruction. Description of a new technique and a preliminary report of its application. Circulation 30: 654-670, 1964

7) Erbstein RA, Wholey MH, Smoot S: Subclavian artery syndrome: Treatment by percutaneous transluminal angioplasty. AJR 151: 291-294, 1988

8) Fischer CM, Gore ON, White PD: Atherosclerosis of the carotid and vertebral arteries. J Neuropathol Exp Neurol 20: 323-379, 1961

9) Imparato AM, Riles TS, Gorstein F: The carotid bifurcation plaque: Pathologic findings associated with cerebral ischemia. Stroke 10: 238-245, 1979

10) Kachel R, Basche S, Heerklotz I: Percutaneous transluminal angioplasty (PTA) of supra-aortic arteries especially the internal carotid artery. Neuroradiology 33: 191-194, 1991

11) Kerber CW, Cromwell LD, Loehden OL: Catheter dilatation of proximal carotid stenosis during distal bifurcation endarterectomy. AJNR 1: 348-349, 1980

12) Mathias K: Perkutane transluminale katheterbehandlung supraaortler Arterienobstruktion. Angiology 3: 47-50, 1981

13) Motarjeme A, Keifer JW, Zuska AJ: Percutaneous transluminal angioplasty of the vertebral arteries. Radiology 139: 715-717, 1981

14) Ringelstein EB, Zeumer H: Delayed reversal of vertebral artery blood flow following percutaneous transluminal angioplasty for subclavian steal syndrome. Neuroradiology 26: $189-198,1984$

15）高橋 明：脳血管領域の血管形成術の経験一器質的動脈狭 窄閉塞と脳血管攣縮の治療. 脳血管攣縮 (スパズムシンポ講 演集）6: 90-107, 1991

16) Theron J, Melançon D, Ethier R: "Pre" subclavian steal syndromes and their treatment by angioplasty. Neuroradiology 27: 265-270, 1985

17) Tsai FY, Matovich V, Hieshima G: Percutaneous transluminal angioplasty of the carotid artery. AJNR 7: 349-358, 1986 